\title{
Seasonality and diversity patterns of microphytobenthos in a mesotrophic lake
}

\author{
N. Aberle A, $^{1,2}$ and K. H. Wiltshire ${ }^{3}$ \\ Max Planck Institute for Limnology, Plön
}

With 5 figures and 3 tables

\begin{abstract}
Investigations on the littoral microphytobenthos populations of lakes are very rare. Based on new sampling techniques, allowing the undisturbed sampling of sublittoral sediments, we present information on limnic microphytobenthos populations of the Schöhsee in Northern Germany $\left(10^{\circ} 26^{\prime} \mathrm{E}, 54^{\circ} 13^{\prime} \mathrm{N}\right)$. Investigations on microphytobenthic communities at a sandy and a muddy site provided new insights into the community structure and seasonal variations of limnic benthic microalgae. The microphytobenthos was characterised by low chlorophyll- $a$ contents $\left(0.16 \mu \mathrm{g} \mathrm{cm}^{-2}\right.$ to $0.74 \mu \mathrm{g} \mathrm{cm}^{-2}$ ) and low cell numbers $\left(25\right.$ cells $\mathrm{cm}^{-2}$ to 266 cells $\mathrm{cm}^{-2}$ ). Both sites showed similar patterns in terms of algal biomass and seasonality; no site-specific characteristics were observed. The productivity of the sediment microflora in the Schöhsee was low and most likely related to the mesotrophic lake character and to reduced light conditions in the near-shore sublittoral. The algal communities at both sites showed high diversity, distinct seasonality and succession patterns with shifts in community composition in spring, summer and autumn. The community was dominated by Fragilaria spp., Navicula spp., Nitzschia spp., and Stauroneis spp. in spring shifting to a Stauroneis spp.-dominated community in summer. In autumn the populations were dominated by Navicula spp., Nitzschia spp., and Stauroneis spp. Overall, the taxonomic composition showed a dominance of prostrate diatoms, whereas cyanobacteria, green algae and erect diatoms occurred rarely and with low abundance. Thus, the sediment microflora of the Schöhsee can be characterized as a flat, two-dimensional community.
\end{abstract}

Key words: low productivity, algal biomass, edaphic algae, epipsammon, sediments.

1 Authors' addresses: Present address: Leibniz Institute of Marine Sciences (IFMGEOMAR), Düsternbrooker Weg 20, 24105 Kiel, Germany.

2 Max Planck Institute for Limnology, August-Thienemann-Str. 2, 24306 Plön, Germany.

3 Biologische Anstalt Helgoland, Stiftung Alfred-Wegener Institute for Polar and Sea Research, P. O. Box 180, 27483 Helgoland, Germany. 


\section{Introduction}

Sediment microflora comprises of microscopic, photosynthetic eukaryotic algae and cyanobacteria that live on or within the sediment. These microorganisms are restricted to the surface layers of sediments due to the depth penetration of light (MACINTYRE et al. 1996) and they therefore play an important role for nutrient and oxygen fluxes at the sediment water interface (JøRGENSEN et al. 1983, WiLTSHIRE et al. 1996). Their occurrence is governed by environmental parameters making them sensitive indicators of water quality (LANGE-BERTALOT 1979) and their key function as primary producers and as a food source in littoral zones has been emphasized in many studies (COLIJN \& DE Jonge 1984, McCormick \& Stevenson 1991, Pinckney \& Zingmark 1993, Hillebrand et al. 2002).

Although the diversity and functional role of microphytobenthic communities has become a major topic in marine benthic research over the last two decades (Sundbaeck \& Joensson 1988, Blanchard 1991, Montagna et al. 1995), its potential importance in the littoral zones of freshwater lakes has received little attention. Consequently, not much is known about the composition, fluctuation and seasonal occurrence of the sediment microflora in freshwater habitats (Lowe 1996). Most studies carried out in freshwater benthic systems focused on epilithic or epiphytic algae growing on solid substrates (Sumner \& McIntire 1982, McCormick \& Stevenson 1991, Kann 1993, Cox 1993, Lowe 1996, HiLlebrand \& KaHLERT 2001). In contrast, studies on epipelic algae (algae moving actively through the sediments by means of their raphes, Round 1971) or epipsammon communities (algae growing attached to sediment particles; Round 1971) are rare (Round 1957, HickMAN \& Round 1970, Miller et al. 1987, KhondKer \& Dokulil 1988, Cyr 1998, NozaKi et al. 2003). This is the case even though soft sediments often represent the main substrate in shallow lakes and epipelic or epipsammic algae can reach high biomass and productivity (KHONDKER \& DoKUlIL 1988, CYR 1998).

To increase our understanding of the specific composition of microphytobenthic communities in temperate regions, a survey was conducted in Schöhsee (Plön, Germany) in the summer of 2001. With respect to planktonic parameters the Schöhsee is well-studied, but, until this study, the benthos had received little attention. This study was aimed at providing first baseline information on the abundance, diversity and seasonal variations of benthic microalgae in the Schöhsee. Both sandy and muddy sediments were examined to evaluate potential differences in community structure and seasonal variations of these poorly understood limnic microalgal communities. We aimed at nondestructive sampling allowing high resolution $(\mu \mathrm{m})$ vertical profiling in order to determine the potential microalgal stratification in the sediments (see WILTSHIRE 2000). 


\section{Material and methods}

\section{Sampling sites}

Investigations on natural microphytobenthic communities were conducted from May to October 2001 in the Schöhsee $\left(10^{\circ} 26^{\prime} \mathrm{E}, 54^{\circ} 13^{\prime} \mathrm{N}\right)$. The Schöhsee has a surface area of $0.78 \mathrm{~km}^{2}$ with a shoreline length of $4.7 \mathrm{~km}$. The mean water depth is $10.9 \mathrm{~m}$, with a maximum depth of $29.4 \mathrm{~m}$. The lake has a small catchment area $\left(2.15 \mathrm{~km}^{2}\right)$ and with its low total phosphorous (average TP $=21 \mu \mathrm{g} \mathrm{L}^{-1}$ ) and low chlorophyll- $a$ contents (average chlorophyll- $a=21 \mu \mathrm{g} \mathrm{L}^{-1}$ ) (GREY et al. 2004) this lake can be categorised as mesotrophic with a low productivity in the water column. The organic carbon contents of sediments range between 13-20 percent by weight at $10 \mathrm{~m}$ water depth and 8.5-30 percent by weight at $15 \mathrm{~m}$ water depth (GREY, pers. comm.). Two different sites were chosen in order to assess potential influence of sediment characteristics (muddy and sandy) on the structure of microalgal communities. The sites were $30 \mathrm{~m}$ apart in the vicinity of the island "Kleiner Warder" at a distance $100 \mathrm{~m}$ from the shore and they had an area of $0.25 \mathrm{~m}^{2}$ each. The sandy site was at a water depth of $0.8 \mathrm{~m}$ whereas the muddy site was at $1.2 \mathrm{~m}$ depth.

\section{Sampling and experimental design}

It is imperative that the structure of microphytobenthos populations is preserved and not disrupted/diluted in the sampling process (see WiLtSHIRE et al. 1997, WiLTSHIRE 2000). This is especially difficult in submerged sediments. To this end, a new sampling technique was developed to keep disturbance of the sediment surfaces to a minimum during sampling. Sediment caps filled with autoclaved natural sediments from the sites were deployed prior to the experiment. These caps were open-ended cylindrical plastic tubes $\left(\varnothing 14 \mathrm{~mm}\right.$, surface area $\left.154 \mathrm{~mm}^{2}\right)$ with a screw cap. A plastic gauze (mesh width of $500 \mu \mathrm{m}$ ) was glued to the bottom of the caps to permitting contact with the sur-

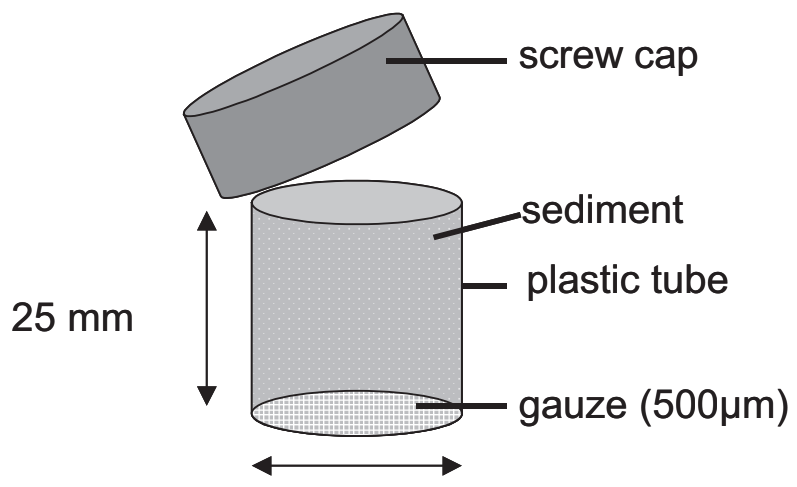

\section{$14 \mathrm{~mm}$}

Fig. 1. Sediment cap (cylindrical plastic tubes) provided with a screw cap for closing in situ. 
rounding sediment and allowing diffusion (Fig. 1). The caps were filled with autoclaved sediment from each site, closed with a lid and frozen to ensure that the structure was maintained and the sediment did not slip out of the cap at insertion. At the beginning of the survey 36 frozen caps were inserted by SCUBA into the sediment at each site. The cap sediment surface layer was aligned flush with the surface of the surrounding sediments and thereafter the lids were removed. The first sampling took place four weeks after the field deployment. Thereafter, once a month, six caps were chosen randomly at each site, closed under water and transferred to a tray in order to keep the samples in an upright position. The sampling caps were returned to the water surface and immediately preserved.

\section{Sample preservation}

The original Cryolander sampling procedure described by WILTSHIRE et al. (1997) was used in a modified manner to sample the Schöhsee sediments. Because the device cannot be used under water, the technique was modified slightly. The Cryolander consists of a brass tube ( $1 \mathrm{~mm}$ thick) which is $50 \mathrm{~mm}$ in diameter and $80 \mathrm{~mm}$ in height. In order to preserve the uppermost surface layer of the caps immediately after the return to the water surface, the Cryolander was placed on top of the sediment surface of each tube and liquid nitrogen $(3-5 \mathrm{ml})$ was then gently dribbled on to the absorbent cotton of the Cryolander. Since the cotton is at ambient temperature, the liquid nitrogen vaporises and this vapour freezes the sediment surface immediately without distortion even on a micrometer scale. Once the surface was frozen, the liquid nitrogen was poured onto it evenly through the Cryolander mesh. The depth of frozen sediment increased rapidly until an approximately $2 \mathrm{~cm}$ thick layer was frozen. The samples were then stored in liquid nitrogen for future use.

\section{Sample processing}

The frozen samples were cut into $1 \mathrm{~cm}$ thin discs in the laboratory. Subsequently the top sediment disc was placed on the stage of a freezing microtome (Leica CM 1900) using a freezing medium to stabilize the sample thus ensuring that the sediment surface was absolutely horizontal. Two $250 \mu \mathrm{m}$ thick slices where then cut off the top; the surface layer from $0-250 \mu \mathrm{m}$ and the deeper layer from $250-500 \mu \mathrm{m}$. A description of the micro-slicing technique is given in WiLTSHIRE (2000). For cell counts and taxa composition these sediment sections were fixed with Lugol's iodide solution, transferred to a Sedgewick-Rafter counting chamber and counted under an inverted light microscope at a $200 \times$ magnification. The microphytobenthos was identified to genus level, as a precise determination of freshwater microphytobenthos to species-level requires a laborious working-up of the samples and the use of an electron microscope which makes unsuitable for the kind of study performed here. Moreover, the present study was geared to determining morphotypes and communities and thus such complexity was not required. This is an accepted way to proceed in the literature (see: Round 1960, Wasmund 1984, Hillebrand \& Kahlert 2001, 2002).

The results from the surface and the sub-surface layer were pooled for taxonomic composition thus the data presented here comprises algal cells from $0-500 \mu \mathrm{m}$ sedi- 
ment depth. Chlorophyll- $a$ sample processing and HPLC-analysis followed the protocol described by WiLTSHIRE (2000).

\section{Statistical analysis}

To test for significant differences in total cell numbers and chlorophyll- $a$ contents for surface and subsurface sediments at both sites, a two-factorial ANOVA with the independent factors horizon (F1) and site (F2) and a Duncan-test were used. For comparisons of seasonality patterns, within each sediment type, a two-factorial ANOVA was used with the independent factors month (F1) and sediment horizon (F2). Diversity indices were calculated and multivariate analyses were carried out using PRIMER 5.2 $\left({ }^{\odot} 2001\right.$ Primer-E Ltd.) and STATISTICA. Diversity was measured by the ShannonWiener function $\left(\mathrm{H}^{\prime} ; \log _{\mathrm{e}}\right.$ ) (SHANNON \& WeAver 1963). The similarity of samples was calculated using MDS ordination analyses, based on untransformed data.

\section{Results}

\section{Chlorophyll-a contents}

The chlorophyll- $a$ concentrations showed significant variations between horizons and sites (Fig. $2 \mathrm{~A} ; \mathrm{p}<0.05$, Table $1 \mathrm{~A}$ ). The chlorophyll- $a$ concentrations at the sediment surface of sandy sediments were significantly higher than on muddy sediments $(\mathrm{p}<0.05$; Duncan test) but these differences disappeared with increasing sediment depth.

The seasonality patterns of total chlorophyll- $a$ contents at the muddy site showed fairly uniform values throughout the whole sampling period (June-October) with no significant differences between months and horizons $(\mathrm{p}>0.05$, Table $2 \mathrm{~A})$.

Table 1. Total chlorophyll- $a(\mathbf{A})$ and total cell numbers $(\mathbf{B})$ at the sandy and the muddy site. Results of a two factorial ANOVA, with horizon (s, d) and site (mud, sand) as independent factors and total chlorophyll- $a$ or total cell numbers as dependent variables.

\begin{tabular}{lrlrr}
\hline & $(d f)$ & MS & $F$-ratio & $P$-level \\
\hline (A) Chlorophyll- $\boldsymbol{a}$ & & & & \\
Horizon & 1 & 0.2126 & 6.5134 & 0.0139 \\
Site & 1 & 0.2505 & 7.6725 & 0.0079 \\
Horizon $\times$ site & 1 & 0.0695 & 2.1291 & 0.1510 \\
Error & 48 & 0.0326 & & \\
$($ B) Cell number & & & & \\
Horizon & 1 & 130314 & 12.67690 & 0.0007 \\
Site & 1 & 17805 & 1.73206 & 0.1927 \\
Horizon $\times$ site & 1 & 39 & 0.00380 & 0.9510 \\
Error & 66 & 10280 & & \\
\hline
\end{tabular}




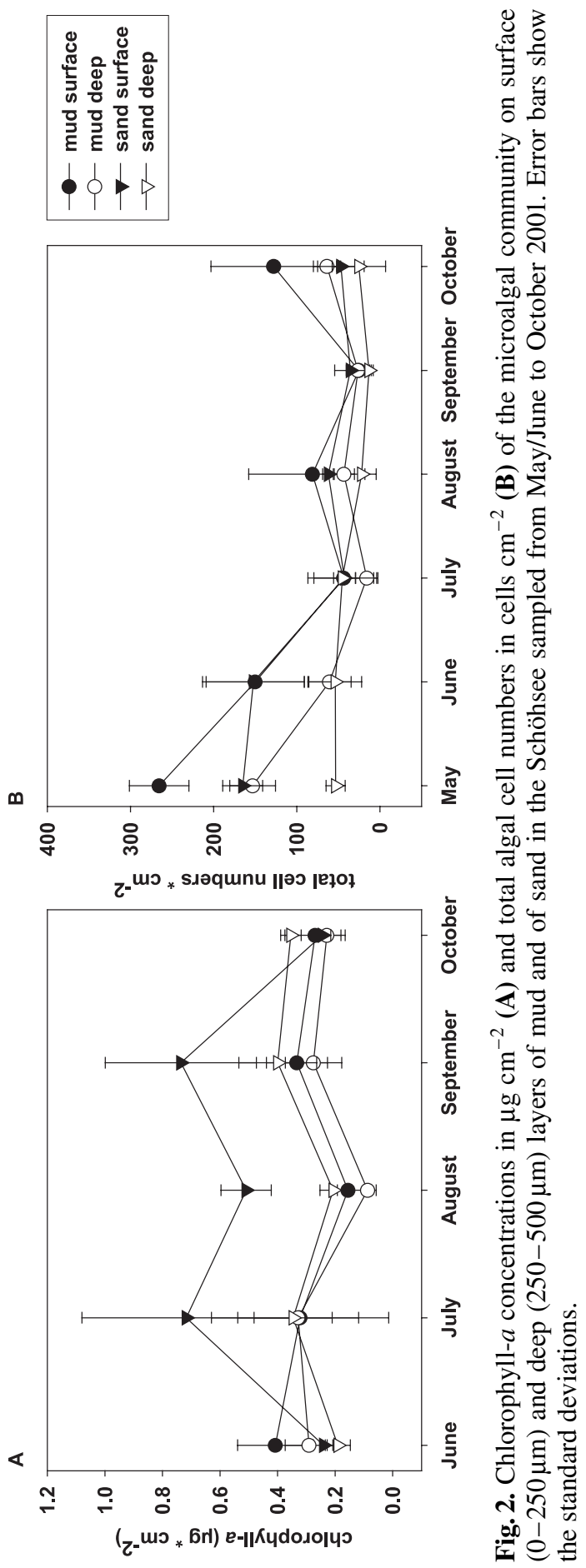


Table 2. Seasonality patterns of chlorophyll- $a$ on mud (A) and on sand (B). Results of a two factorial ANOVA, with month (June-October) and horizon (s, d) as independent factors and total chlorophyll- $a$ as dependent variable.

\begin{tabular}{lrlll}
\hline & $(d f)$ & MS & $F$-ratio & $P$-level \\
\hline (A) Mud & & & & \\
Month & 4 & 0.0496 & 2.3980 & 0.0843 \\
Horizon & 1 & 0.0230 & 1.1129 & 0.3040 \\
Month $\times$ horizon & 4 & 0.0030 & 0.1449 & 0.9631 \\
Error & 20 & 0.0207 & & \\
(B) Sand & & & & \\
Month & 4 & 0.1049 & 3.7442 & 0.0335 \\
Horizon & 1 & 0.1937 & 6.9085 & 0.0220 \\
Month $\times$ horizon & 4 & 0.0465 & 1.6581 & 0.2238 \\
Error & 12 & 0.0280 & & \\
\hline
\end{tabular}

Chlorophyll- $a$ concentrations at the sandy site showed significant variations between months and horizons $(\mathrm{p}<0.05$, Table 2 B). Significantly higher chlorophyll- $a$ contents at the sediment surface were detected in July and September when compared to June and the surface values in October where significantly lower than in September ( $p<0.05$; Duncan test). In contrast to the muddy site, a significant difference between surface and subsurface sediments was found on sand $(\mathrm{p}<0.05$; Duncan test).

\section{Total cell numbers}

The total cell numbers also showed significant variations between sediment horizons (Fig. 2 B; p $<0.05$, Table 1 B) no differences between the sites were found (Fig. $2 \mathrm{~B} ; \mathrm{p}<0.05$, Table $1 \mathrm{~B}$ ). The total cell number at both sites was highest in May and a decline during the summer and autumn period could be detected (Fig. 2 B; p < 0.05, Table $1 \mathrm{~A}$ and B). At both sites, algal abundance was higher in the surface layer $(0-250 \mu \mathrm{m})$ than in the deeper layer $(\mathrm{p}<0.05$, Table 1 A and B). Lowest surface cell numbers were found for September for both the muddy and the sandy substrate. A slight increase was found in the surface layer in October.

For the muddy sediment, the surface cell numbers in May surface showed significant differences when compared to all other months $(\mathrm{p}<0.05$, Duncan test). In addition, the June algal abundance in the surface layer was significantly different to May, July and September ( $p<0.05$, Duncan test). The surface sediments sampled in September and October were significantly different from one another $(\mathrm{p}<0.05$, Duncan test). For subsurface layers significantly higher cell numbers were detected in May compared to samples taken from June to October ( $\mathrm{p}<0.05$, Duncan test). 
Table 3. Seasonality patterns of cell numbers on mud (A) and on sand (B). Results of a two factorial ANOVA, with month (May-October) and horizon (s, d) as independent factors and total chlorophyll- $a$ as dependent variable.

\begin{tabular}{lrlrr}
\hline & $(d f)$ & MS & $F$-ratio & $P$-level \\
\hline (A) Mud & & & & \\
Month & 5 & 65464 & 16.4724 & 0.0000 \\
Horizon & 1 & 64770 & 16.2978 & 0.0005 \\
Month $\times$ horizon & 5 & 6233 & 1.5684 & 0.2069 \\
Error & 24 & 3974 & & \\
(B) Sand & & & & \\
Month & 5 & 19847 & 5.3783 & 0.0022 \\
Horizon & 1 & 70528 & 19.1123 & 0.0002 \\
Month $\times$ horizon & 5 & 8833 & 2.3938 & 0.0706 \\
Error & 22 & 3690 & & \\
\hline
\end{tabular}

For the sandy site significant differences between months were found at the surface $(\mathrm{p}<0.05$, Duncan test) but not for the subsurface layer $(\mathrm{p}>0.05$, Duncan test). The cell numbers at the sediment surfaces showed significant differences between the samples taken in May, June and August compared to surface sediments sampled in July, September and October $(\mathrm{p}<0.05$, Duncan test).

\section{Taxonomic composition}

The sandy as well as the muddy sediments were colonized by similar algal assemblages and both sites showed the same seasonality patterns.

The ordination analysis between months on the muddy site showed similarities of algal communities sampled in May and June (Fig. 3). In both months Fragilaria spp. (17-19\%), Navicula spp. (12-19\%), Nitzschia spp. (5-13\%), Stauroneis spp. (8-9\%) and Pinnularia spp. (4-13\%) were dominant (Fig. 4 A). The chain-forming benthopelagic Melosira spp. comprised 5-6\% of the total algal community. The genus Synedra spp. was present in both months but showed a strong dominance only in June (35\%). In addition, filamentous green algae comprised $5 \%$ to the total algal community in May and the colonial green algae Pediastrum spp. $1 \%$ whereas cyanobacteria were not present at all. The numbers of green algae decreased dramatically in June. In July a transition phase started and from this month onwards the algal community changed to a Stauroneis spp.-dominated population, which contributed from 28 to $43 \%$ to the total algal community (Fig. 3). Other dominant taxa were: Synedra spp. (11-15\%), Navicula spp. (11-19\%) and Pinnularia spp. (11-13\%) and remained similar until September. In addition, the taxon Gyrosigma spp. was highly abundant in July (20\%). In October these distribution patterns changed and a clear dominance of Nitzschia spp. was seen $(35 \%)$. 


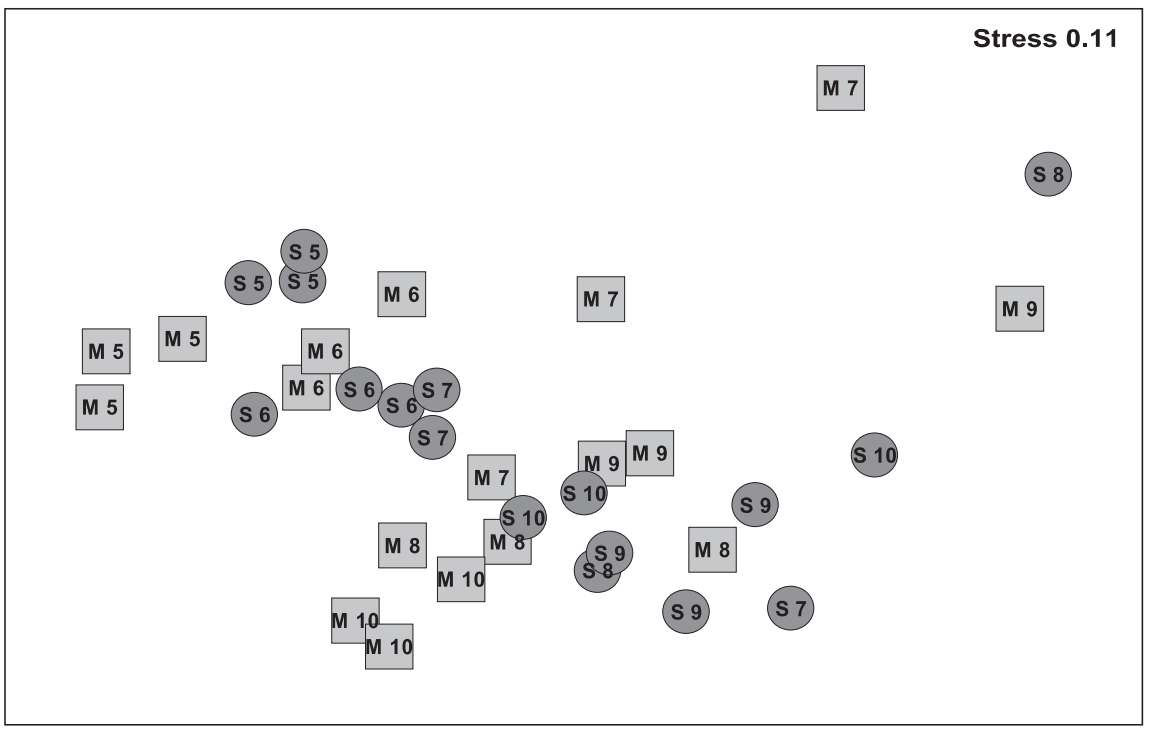

Fig. 3. Similarities (\%) in taxonomic composition between algal communities of different months on mud (M) and on sand (S) in the Schöhsee sampled from May (M5, S5) to October (M10, S10) resulting from MDS ordination analysis. Absolute cell numbers in the top $500 \mu \mathrm{m}$ of the sediments are considered.

Other abundant taxa in October were: Diploneis spp. (15\%), Stauroneis spp. $(16 \%)$ and Pinnularia spp. (11\%). From July to October no green algae and no cyanobacteria were found, a feature which most likely contributed to similarities between the summer and the autumn communities that were revealed from ordination analysis (Fig. 3).

On the sandy substrate similar distribution and seasonality patterns were found to the muddy sediment. Ordination analysis revealed similarities between May and June samples (Fig. 3). Both months showed high percentages of Synedra spp. (23-30\%), Fragilaria spp. (14-17\%) and Navicula spp. (13$14 \%$ ) (Fig. 4B). In June Stauroneis spp. had increased to $16 \%$ of the total algal community and the genus Amphora appeared (5\%). In addition, the green algae Pediastrum spp. comprised of up to $5 \%$ of the total algal community in May and up to $6 \%$ in June whereas cyanobacteria were missing. With the start of the summer period the samples changed in composition. In July the algal community still showed patterns similar to those found in May and June (Fig. 3). Cell numbers of Stauroneis spp. (30\%) and Amphora spp. (10\%) increased whereas percentages of Navicula spp., Synedra spp. and Fragilaria spp. decreased. During the summer (July-September) Stauroneis spp. (30$47 \%$ ) and Synedra spp. (11-23\%) dominated. The genus Amphora spp. (6$10 \%)$, Navicula spp. (5-15\%) and Pinnularia spp. (8-9\%) contributed less to 


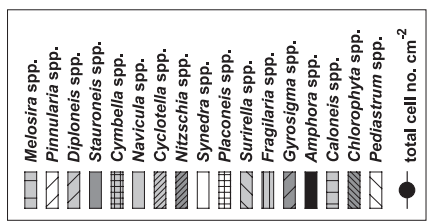

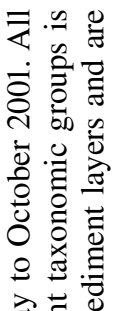

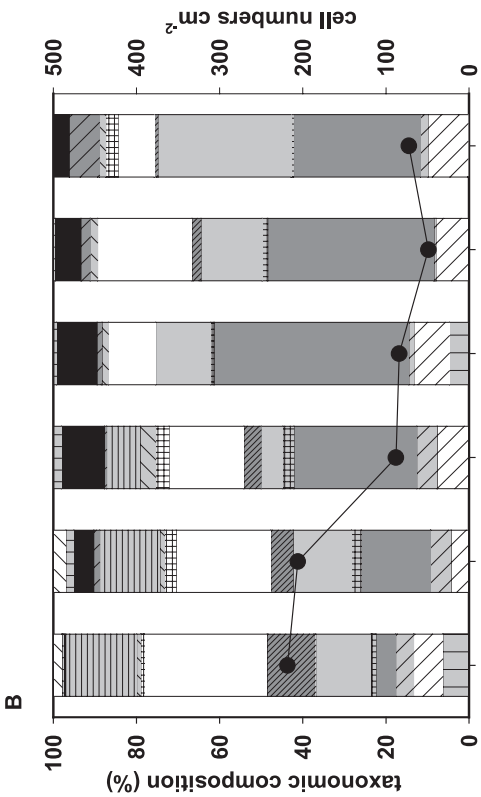

胥

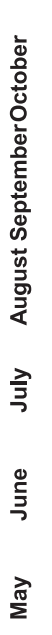

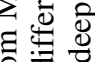

융 잉

Ч

\&

胥芯

的

ष

:은

语䎡

동

$=\dot{\infty}$

$\exists \cdot \frac{0}{8}$

๑) ڤ

플 중

के

จ ํำ

등 ㅅำ

च

«过兽

응 ల

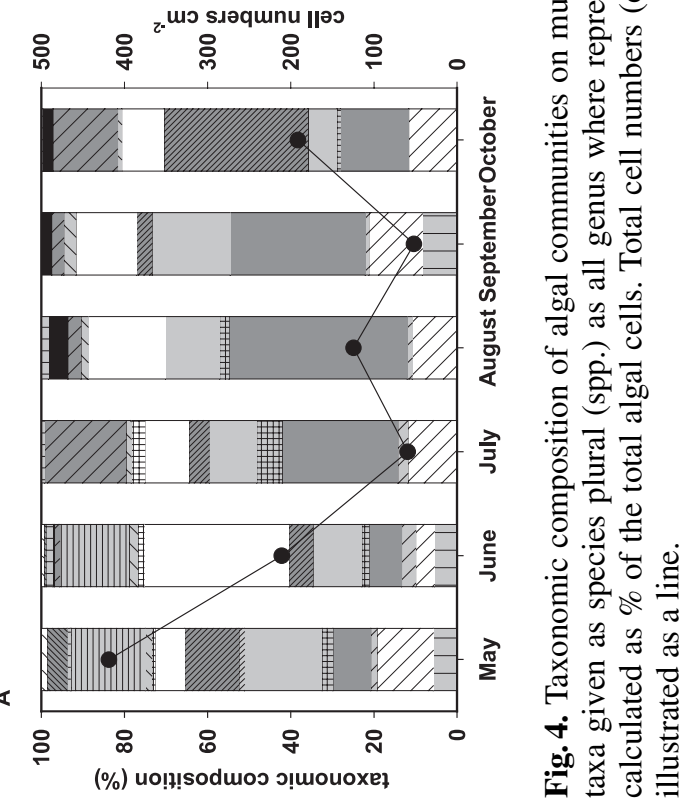


the total algal community. In October the microphytobenthic assemblage was co-dominated by Navicula spp. (32\%) and Stauroneis spp. (31\%) and Synedra-cells decreased in number (9\%). Pinnularia spp. made up $10 \%$ of the autumn community and Gyrosigma spp. appeared (7\%). As for algal communities on mud, no green algal and no cyanobacteria taxa were found in the summer and autumn leading to similarities between both seasons (Fig. 3).

\section{Diversity}

The diversity index $\mathrm{H}^{\prime}$ (referring to changes in the number of taxa) for the sandy and the muddy substrates showed similar diversity patterns. Diversity was significantly higher in May, June and July compared to August $(\mathrm{p}<0.05)$ where the diversity reached a minimum on mud and on sand (Fig. 5). Diversity slightly increased again in September and October although the diversity in September was still significantly lower than in May $(\mathrm{p}<0.05)$.

\section{Discussion}

This study aimed at identifying seasonal community patterns in unproductive lakes and to improve our knowledge on lake systems in general. By comparing two different substrate types, the heterogeneity of microphytobenthos was considered and first high resolution vertical profiles for sublittoral microphytobenthos in freshwater systems are presented. As investigations on microphytobenthic populations in limnic habitats are rare, our investigations con-

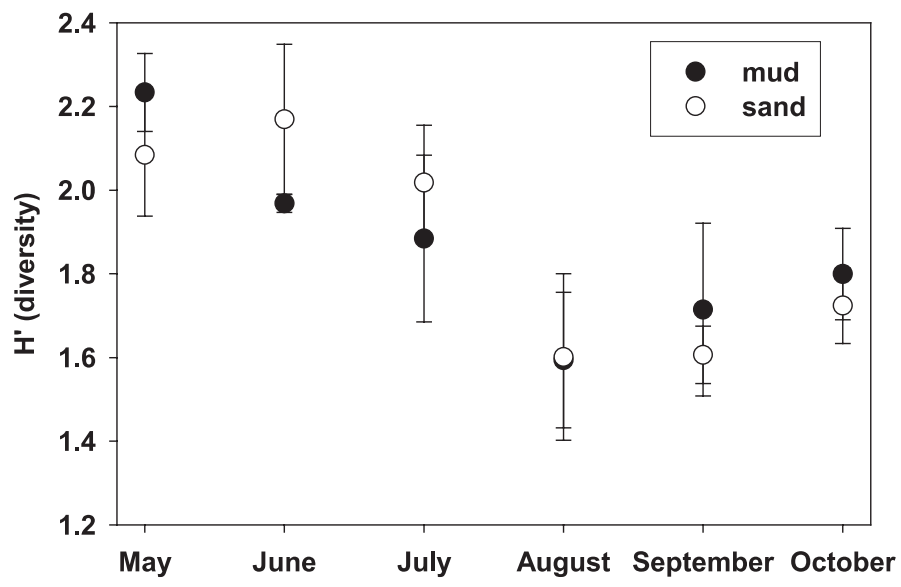

Fig. 5. Diversity $\left(\mathrm{H}^{\prime}\right)$ of the algal community on mud and on sand in the Schöhsee sampled from May to October 2001. Mean values and error bars as standard deviations (SD) are given. 
tribute to a further understanding of freshwater sediment microflora communities.

\section{Sampling methodology}

The successive sampling of sediments is highly disruptive and destructive in sediments. When addressing succession patterns in microphytobenthos communities, it is imperative not to destroy the surface matrix of the surrounding sediment. Compounding this is the fact that the methods (e.g. sawn-off syringes or coring) are highly unreliable when it comes to the upper layer of sediments (WILTSHIRE et al. 1997, WiLtShiRe 2000) and, furthermore, they are particularly unreliable under water. Thus, we had to develop a new way of sampling underwater sediments for successional patterns of microalgae in the surface millimetres. The cylindrical caps used in this study were filled with autoclaved sediments and were transferred to the sediment site where they were colonized by microalgae. The colonization period prior to sampling was four weeks and due to the normally very rapid microalgae re-colonization of sediments covered with water, e.g. six days for intertidal sediments (UNDERWOOD \& PATERSON 1993), the bare sediment was likely in equilibrium with the surrounding sediments after one month. Furthermore, our data also showed the classical decreases in microalgal abundance after its climax population since the cell numbers from May to June at both sites had already declined considerably.

\section{Chlorophyll-a contents}

The total chlorophyll- $a$ content (uppermost surface layer of $0-500 \mu \mathrm{m}$ ) showed similar concentrations at both sites. Compared to other studies on lake sediments these values are at the lower end of concentrations measured in Neusiedlersee (KHONDKER \& DoKULIL 1988), Lake Mikolajskie (WASMUND 1984), Lake Biwa (NozAKI et al. 2003) and at three lakes in Southern Ontario (CYR 1998). One possible explanation for higher chlorophyll- $a$ concentrations detected in previous studies might be related to the different methods used. Classical photometric or fluorometric techniques, for example, tend to overestimate chlorophyll content (Gieskes \& KraAy 1982, Schanz \& Rai 1988).

We sampled the absolute surface without mixing it with sediments below. This can either dilute a sediment with the non-chlorophyllous material in sediments with sharply decreasing chlorophyll gradients or increase the values per surface unit if for example a sediment has a deep chlorophyll layer (WILTSHIRE 2000). In contrast to our study, previous studies used the first top centimetre of the sediment surface in order to detect total chlorophyll- $a$ contents. Thus, the pigment concentrations measured also include chlorophyll- $a$ from 
deeper sediment layers. WASMUND (1989), for example, found that appreciable amounts of intact chlorophyll- $a$ could be found down to $10 \mathrm{~cm}$ sediment depths and consequently these pigments were situated below the depth to which light penetrates. However, a significant portion of chlorophyll- $a$ found at deeper sediment layers originates from older settled planktonic material (STEVENSON et al. 1985, WASMUND 1989), which is not distinguishable from benthic microalgae chlorophyll- $a$. Therefore, in lakes with a high contribution of planktonic biomass to the sediments, detecting chlorophyll- $a$ from surface sediments at a centimetre scale may lead to an overestimation of chlorophyll- $a$ derived from benthic microalgae alone.

Additionally, in studies where much higher chlorophyll- $a$ concentrations occurred, they were usually correlated with mass occurrence of particular algal taxa. NozAKI et al. (2003), for example found that the development of filamentous green algae contributed to a sharp increase in algal biomass from April to June in Lake Biwa as a result of eutrophication. This was supported by several studies showing a strong link between mass occurrences of green or blue-green benthic microalgae in relation to high water column nutrients (Kann 1940, Kann 1993, Hillebrand \& Kahlert 2001). The absence of such mat- or filament-forming algae in our study is most likely responsible for low chlorophyll- $a$ concentrations of sediments in the mesotrophic Schöhsee, a feature that might be typical for unproductive lakes.

The microscale vertical distribution of chlorophyll- $a$ showed different patterns for the muddy and the sandy site. On the muddy substrate the surface layer chlorophyll- $a$ concentration was similar to the sub-surface layer values whereas on sandy substrate higher values were found at the sediment surface when compared to deeper sediment layers. As total chlorophyll- $a$ concentration are known to decline with increasing sediment depth (WASMUND 1984) and highest chlorophyll- $a$ concentrations are usually found in the surficial millimetre of sediments (GAETJE 1992, Wiltshire 2000), the distribution patterns found on mud seem surprising. The high chlorophyll- $a$ concentrations at deeper layers are, however, most likely related to the physiological status of the microphytobenthos when depth penetration of light is low (WASMUND 1984, Pinckney \& Zingmark 1991, Macintyre et al. 1996). We know from studies on intertidal sediments that the depth profiles even in the upper millimetre of sediments can vary from sharp surficial gradients with all the microalgae concentrated at the surface to diffuser gradients in sediments evincing bioturbation or turbulence (see Wiltshire 2000).

\section{Cell numbers}

At both sites cell numbers showed a maximum in spring followed by a summer decline and higher numbers again in autumn. The spring maximum is 
consistent with seasonality patterns investigated for different lake systems all over the world (Kann 1940, Round 1960, KHONDKer \& Dokulil 1988, NoZAKI et al. 2003), as nutrient and light availability are generally high at this time of the year. During summer, water column nutrients become depleted and macrophyte growth increases in the littoral zones and reduces light availability to a large extent. Thus, due to shading, a decline of sediment microalgal abundances must be expected. In Schöhsee the presence of large Alder populations (Alnus sp.) contribute to the shading of the littoral zone. Evidence for decreasing light intensities at the experimental sites in summer is also evinced in the increased development of adjacent populations of Chara aspera, which is known to be highly adapted to low light regimes (KANN 1940, BLINDOW 1992). In addition, the decline in cell numbers during summer could be related to grazing. Most benthic consumers show high abundances in summer and thus, grazing losses often exceed microalgal production at this time of the year. The distinctive grazers present at the sites were the isopod Asellus aquaticus and the snail Potamopyrgus antipodarum. These findings are supported by several studies showing that such summer depressions of microphytobenthic biomass are directly related to high grazer efficiencies (ColiJn \& DIJKEMA 1981, GAETJE 1992).

When addressing general seasonality patterns for lake microphytobenthos, one is confronted with large variations in nutrient and light conditions between lakes. However, given the similarities in seasonality observed in the Schöhsee, Lake Biwa (NozAKI et al. 2003), in lakes from the English Lake District (Round 1960) and in several other northern German lakes (KANN 1940), we now have further evidence that the occurrence and composition of freshwater microphytobenthic communities is generally controlled by the same major drivers, such as seasonality. Similar to planktonic systems in temperate waters, this includes a spring bloom of the microphytobenthos followed by a summer decline and a second but reduced maximum in autumn.

Cell numbers at both sites were highest in the uppermost surface layer and decreased with increasing sediment depth, as the light availability is higher at the sediment surface and photosynthesis is restricted to a very thin layer at the sediment surface (WASMUND 1984, CARLton \& WeTZEL 1987).

When comparing total chlorophyll- $a$ contents and cell numbers no positive correlation was found. Usually both parameters are used to describe biomass characteristics of algal communities and good correlations have been found (KhondKer \& Dokuli 1988, Mitbavkar \& Anil 2002). However, the total chlorophyll- $a$ content of algal communities is highly variable depending on, e. g. the physiological status of algal cells, cell sizes and light intensities (WOLFF 1979) and thus a correlation should not be assumed or even really expected. 


\section{Taxonomic composition and diversity}

The microphytobenthos in general includes representatives of several algal classes (Baccilariophyceae, Chlorophyceae, Cyanobacteria, Dinophyceae). On sandy and muddy substrates, edaphic microalgae are often dominated by diatoms (Round 1957, 1960, Hickman \& Round 1970, Admiraal 1984, Colijn \& DE Jonge 1984) whereas coccal and filamentous green algae and Cyanobacteria are usually known to occur at some seasonal stages (HILLEBRAND \& KAHLERT 2001, NozAKI et al. 2003).

The taxonomic composition of the sediment microflora in our study was almost exclusively restricted to diatom communities, a feature that is most likely typical for mesotrophic lakes. As already mentioned before, mass occurrences of green algae or cyanobacteria are known to be directly linked to high water column nutrient loadings (KANN 1940, 1993, Hillebrand \& KaHLERT 2001, NozaKI et al. 2003). In unproductive lakes, however, diatom-dominated sediment communities seem to be favoured as they are in general assumed as not being limited by nutrients since nutrient concentrations in the sediment pore water are high (CAdÉE \& HEgemann 1974, AdmiraAl 1984, UnderWOOD \& KROMKAMP 1999) and, furthermore, they are highly effective in accessing nutrients at the sediment-water interface (ADMIRAAL 1984, SUNDBaeck et al. 1991, Wiltshire 1993, Paterson et al. 1998, Hillebrand \& KAHLERT 2002). These characteristics promote a higher competitiveness of benthic diatoms in unproductive lakes, a feature that is supported by the fact that the occurrence of blue green algae is in general restricted to the spring season when enough nutrients from the water column are still available (HILLEBRAND \& KAHLERT 2001, NOZAKI et al. 2003).

In addition to nutrient availability, light conditions can regulate colonization patterns of microalgal communities. As described by KANN (1940), benthic diatoms have a highly adaptive photosynthetic pigment apparatus and are well adapted to low-light regimes. Depending on the light intensity, seasonal shifts in the xanthophyll cycle have been shown (WILTSHIRE et al. 1997) and thus, viability of diatoms at different light regimes is related to their adaptive potential. In contrast to chlorophyll- $a$, these pigments have more efficient photosynthetic yields and light absorption capacities and therefore they enable diatoms to grow at low-light conditions. The two investigation sites of this study were situated in the upper sublittoral zone with a north-easterly orientation and they were characterized by large Alder-populations and vast Chara aspera-meadows. Thus, it seems likely that in our study diatoms were better adapted to shading than other algal classes due to their high resilience to low light conditions (KANN 1940, WILTSHIRE et al. 1997).

The diversity detected for Schöhsee sediments at both sites showed high values similar to the only comparable data from Neusiedlersee (KHONDKER \& 
DokULIL 1988). Most of the dominant taxa were pennate, prostrate forms, which were either epipsammic or epipelic. Prostrate forms are typical for variable environments (mixed sediments) where disturbance, predominantly through wave action or current, plays an important role in structuring the algal community. On highly exposed substrates, however, algal communities have been found to be dominated by epipsammic forms (WOLFF 1979). In contrast to epiphytic or epilithic communities, unstable sediments are usually colonized by prostrate diatoms, forming distinctly flat, two-dimensional communities (MILlER et al. 1987). The microphytobenthic communities of the Schöhsee thus indicate an intermediate degree of hydrographic exposure.

In this study, the two sites were colonized by similar seasonality patterns and algal communities. A clear succession from spring to summer was observed. The spring populations observed in the Schöhsee are similar to the ones described for the Neusiedlersee (KHONDKER \& DoKULI 1988) and for the English Lake District (Round 1960). The autumn community showed clear changes in algal populations in contrast to Lake Mikolajskie (WASMUND 1984) and the Neusiedlersee (KHONDKER \& DoKULI 1988) where the autumn microflora was similar to the one in spring.

However, some typical forms like Cocconeis spp. or Achnanthes spp., often found attached to sediment particles were missing at our sites. In addition, only one erect form was present in considerable amounts throughout the season and this was the genus Synedra. This microalga has the ability to stick to surfaces by forming mucilage pads and apparently this feature made it possible for the algae to grow well even on unstable substrates. Only two other erect forms were found periodically- the chain-forming diatoms Fragilaria spp. and Melosira spp.. The vegetative cells of both diatoms occurred mainly in spring at the sediment surfaces and as these taxa are known to have benthopelagic life cycles (Round et al. 1990), it seems likely that they had settled from the water column and inhabited, for a short time period, the surface of the sediments.

In conclusion, it can be said that the microphytobenthos community of this mesotrophic lake was characterized by low algal biomass comprising almost exclusively of diatoms. The two-dimensional structure was related to the absence of overstory algae and a higher competitiveness and resilience of diatoms to low productivity, reduced light conditions and an intermediate degree of exposure. Distinct seasonality patterns as for lakes with similar conditions were observed. Similar abiotic conditions are common for a multitude of lake systems in temperate regions and thus, the characteristics observed within this study can be regarded as typical features of mesotrophic lakes at higher latitudes. 


\section{Acknowledgements}

We would like to thank Arne MaLzahn for his help during the field sampling as well as for valuable discussions on the manuscript. WINFRIED LAMPERT is thanked for his support and for helpful ideas. The comments of three anonymous reviewers helped us to improve the manuscript considerably. We acknowledge the funding of this work by the "Deutsche Forschungsgemeinschaft" (DFG-Förderzeichen WI 1810/2-1).

\section{References}

AdmiraAl, W. (1984): The ecology of estuarine sediment inhabiting diatoms. - Prog. Phycol. Res. 3: 269-322.

BLANChaRD, G. F. (1991): Measurement of meiofauna grazing rates on microphytobenthos is primary production a limiting factor. - J. Exp. Mar. Biol. Ecol. 147: 3746.

BLINDOw, I. (1992): Long- and short-term dynamics of submerged macrophytes in two shallow eutrophic lakes. - Freshwat. Biol. 28: 15-27.

Cadée, G. C. \& Hegeman, J. (1974): Primary production of the benthic microflora living on tidal flats in the Dutch Wadden Sea. - Neth. J. Sea Res. 8: 260-291.

Carlton, R. G. \& Wetzel, R. G. (1987): Distributions and fates of oxygen in periphyton communities. - Can. J. Bot. 65: 1031-1037.

Colijn, F. \& De Jonge, V. N. (1984): Primary production of microphytobenthos in the Ems-Dollard Estuary. - Mar. Ecol. Prog. Ser. 14: 185-196.

Colijn, F. \& Dijkema, K. S. (1981): Species composition of benthic diatoms and distribution of chlorophyll a on an intertidal flat in the Dutch Wadden Sea. - Mar. Ecol. Prog. Ser. 4: 9-21.

Cox, E. J. (1993): Freshwater diatom ecology: Developing an experimental approach as an aid to interpreting field data. - Hydrobiologia 269-270: 447-452.

CYR, H. (1998): How does the vertical distribution of chlorophyll vary in littoral sediments of small lakes? - Freshwat. Biol. 40: 25-40.

De Jonge, V. N. \& Colijn, F. (1994): Dynamics of microphytobenthos biomass in the Ems estuary. - Mar. Ecol. Prog. Ser. 104: 185-196.

GaEtJe, C. (1992): Artenzusammensetzung, Biomasse und Primärproduktion des Mikrophytobenthos des Elbe-Ästuars. - Ph. D. Thesis, 211 pp. Universität Hamburg.

Gieskes, W. W. C. \& KraAy, G. W. (1982): Comparison of chromatographic methods (HPLC and TLC) with conventional methods for the measurement of chlorophylls in oceanic waters. - Arch. Hydrobiol. Beih. Ergebn. Limnol. 16: 123.

Grey, J., Kelly, A. \& JoNES, R. J. (2004): High intraspecific variability in carbon and nitrogen stable isotopes of lake chironomid larvae. - Limnol. Oceanogr. 49: 239_ 244.

Hickman, M. \& Round, F. E. (1970): Primary production and standing crops of epipsammic and epipelic algae. - Br. Phycol. J. 5: 247-255.

Hillebrand, H. \& KahleRT, M. (2001): Effect of grazing and nutrient supply on periphyton biomass and nutrient stoichiometry in habitats of different productivity. - Limnol. Oceanogr. 46: 1881-1898.

- - (2002): Effect of grazing and water column nutrient supply on biomass and nutrient content of sediment microalgae. - Aquat. Bot. 72: 143-159. 
Hillebrand, H., Kahlert, M., Haglund, A. L., Berninger, U. G., Nagel, S. \& Wickham, S. (2002): Control of microbenthic communities by grazing and nutrient supply. - Ecology 83: 2205-2219.

Jørgensen, B., Revsbech, N. \& Cohen, Y. (1983): Photosynthesis and structure of benthic microbial mats: Microelectrode and SEM studies of four cyanobacterial communities. - Limnol. Oceanogr. 28: 1075-1093.

KANN, E. (1940): Ökologische Untersuchungen an Litoralalgen ostholsteinischer Seen. - Arch. Hydrobiol. 37: 177-269.

- (1993): The littoral algal biocoenoses of lake Erken and its outlet (Uppland, Sweden). - Arch. Hydrobiol. Suppl. 97, Algol. Stud. 69: 91-112.

KHONDKER, M. \& DoKuliL, M. (1988): Seasonality, biomass and primary productivity of epipelic algae in a shallow lake (Neusiedlersee, Austria). - Acta Hydrochim. Hydrobiol. 16: 499-515.

LanGe-BerTalOT, H. (1979): Tolerance and population dynamics of benthic diatoms under varying waste water loading. - Arch. Hydrobiol. 56: 184-219.

Lowe, R. (1996): Periphyton patterns in lakes. - In: Lowe, R. (ed.): Algal Ecology: Freshwater benthic ecosystems. - Academic Press, San Diego, pp. 57-76.

Macintyre, H. L., Geider, R. J. \& Miller, D. C. (1996): Microphytobenthos: The ecological role of the "secret garden" of unvegetated, shallow-water marine habitats. 1. Distribution, abundance and primary production. - Estuaries 19: 186-201.

McCormick, P. V. \& Stevenson, R. J. (1991): Grazer control of nutrient availability in the periphyton. - Oecologia 86: 287-291.

Miller, A. R., Lowe, R. L. \& RotenberRy, J. T. (1987): Succession of diatom communities on sand grains. - J. Ecol 75: 693-710.

Mitbavkar, S. \& ANiL, A. C. (2002): Diatoms of the microphytobenthic community: population structure in a tropical intertidal sand flat. - Mar. Biol. 140: 41-57.

Montagna, P. A., Blanchard, G. F. \& Dinet, A. (1995): Effect of production and biomass of intertidal microphytobenthos on meiofaunal grazing rates. - J. Exp. Mar. Biol. Ecol. 185: 149-165.

Nozaki, K., KhadbaAtar, D., Tetsuji, A., Naoshige, G. \& Osamu, M. (2003): Development of filamentous green algae in the benthic algal community in a littoral sand-beach zone of Lake Biwa. - Limnology 4: 161-165.

Paterson, D. M., Wiltshire, K. H., Miles, A., Blackburn, J., Davidson, I., Yates, M. G., McGrorty, S. \& EAstwood, J. A. (1998): Microbiological mediation of spectral reflectance from intertidal cohesive sediments. - Limnol. Oceanogr. 43: $1207-1221$.

Pinckney, J. L. \& Zingmark, R. G. (1991): Effects of tidal stage and sun angles on intertidal benthic microalgal productivity. - Mar. Ecol. Prog. Ser. 76: 81-89.

- - (1993): Modelling the annual production of intertidal benthic microalgae in estuarine ecosystems. - J. Phycol. 29: 396-407.

Round, F. E. (1957): Studies on the bottom living algae in some lakes of the English Lake District II: the distribution of Bacillariophyceae on the sediments. - J. Ecol. 45: $343-360$.

- (1960): Studies on the bottom living algae in some lakes of the English Lake District IV: the seasonal cycle of Bacillariophyceae. - J. Ecol. 48: 529-547.

- (1971): Benthic marine diatoms. - Oceanogr. Mar. Biol. Ann. Rev. 9: 83-139.

Round, F. E., Crawford, R. M. \& Mann, D. G. (1990): The diatoms: Biology and morphology of the genera. Cambridge University Press, Cambridge (UK). 
Schanz, F. \& RaI, H. (1988): Extract preparation and comparison of fluorometric, chromatographic (HPLC) and spectrophotometric determinations of chlorophyll-a. - Arch. Hydrobiol. 112: 533-539.

ShanNon, C. \& WeAVer, W. (1963): The Mathematical Theory of Communication. University of Illinois Press, Urbana.

Stevenson, R. J., Singer, R., Roberts, D. A. \& Boylen, C. W. (1985): Patterns of benthic algal abundance with depth, trophic status, and acidity in poorly buffered New Hampshire lakes. - Can. J. Fish. Aquat. Sci. 42: 1501-1512.

Sumner, W. T. \& McIntiRe, C. D. (1982): Grazer periphyton interactions in laboratory streams. - Arch. Hydrobiol. 93: 135-157.

Sundbaeck, K., ENOKSSON, V., Graneli, W. \& Pettersson, K. (1991): Influence of sublittoral microphytobenthos on the oxygen and nutrient flux between sediment and water: A laboratory continuous-flow study. - Mar. Ecol. Prog. Ser. 74: $263-$ 279.

Sundbaeck, K. \& Joensson, B. (1988): Microphytobenthic productivity and biomass in sublittoral sediments of a stratified bay Southeastern Kattegat, North Sea. - J. Exp. Mar. Biol. Ecol. 122: 63-82.

Underwood, G. J. C. \& Kromkamp, J. (1999): Primary production by phytoplankton and microphytobenthos in estuaries. - Adv. Ecol. Res. 29: 93-153.

Underwood, G. J. C. \& Paterson, D. M. (1993): Recovery of intertidal benthic diatoms after biocide treatment and associated sediment dynamics. - J. Mar. Biol. Assoc. U. K. 73: $25-45$.

WaSMUND, N. (1984): Production and distribution of the microphytobenthos in the sediment of Lake Mikolajskie. - Internat. Rev. ges. Hydrobiol. 69: 215-229.

- (1989): Micro-autoradiographic determination of the viability of algae inhabiting deep sediment layers. - Est. Coast. Shelf Sci. 28: 651-656.

WiLtshiRe, K. H. (1993): The influence of photosynthetic oxygen production by microphytobenthos on the oxygen and nutrient status of sediment water systems in the Elbe estuary. - Verh. Internat. Verein. Limnol. 25: 1141-1146.

- (2000): Algae and associated pigments of intertidal sediments, new observations and methods. - Limnologica 30: 205-214.

Wiltshire, K. H., Blackburn, J. \& Paterson, D. M. (1997): The Cryolander: A new method for fine-scale in-situ sampling of intertidal surface sediments. - J. Sed. Res. 67: 977-981.

Wiltshire, K. H., Schroeder, F. Knauth, H.-D. \& Kausch, H. (1996): Oxygen consumption and production rates and associated fluxes in sediment-water systems: A combination of microelectrode, incubation and modelling techniques. Arch. Hydrobiol. 137: 457-486.

WoLfF, W. J. (1979): Flora and Vegetation of the Wadden Sea. - Report 3 (Final Report of the Section Marine Biology of the Wadden Sea), Balkema A. A., Rotterdam (Netherlands); pp. 206.

Submitted: 28 May 2005; accepted: 26 January 2006. 